\title{
Pengaruh Terapi Kelompok Terapeutik terhadap Kemampuan Keluarga dalam Memberikan Stimulasi Perkembangan Rasa Percaya Usia Bayi di Kelurahan Batu Ampar Kramatjati Jakarta Timur Tahun 2010
}

\author{
Rika Damayanti
}

Dosen Fakultas Tarbiyah dan Keguruan, IAIN Raden Intan Lampung

Diterima: Oktober 2014. Disetujui: November 2014. Dipublikasikan: Desember 2014

\begin{abstract}
Abstrak: Tujuan penelitian ini adalah memperoleh gambaran tentang pengaruh terapi kelompok terapeutik terhadap kemampuan keluarga menstimulasi perkembangan bayi serta perkembangan rasa percaya di kelurahan Batu Ampar Kramatjati Jakarta Timur. Desain penelitian adalah "Quasi experimental pre-post test with kontrol group". Sampel adalah purposive sampling dengan besarnya sampel 80 keluarga yang mempunyai bayi. Terapi Kelompok Terapeutik dilakukan dengan tujuh sesi pertemuan tentang cara memberikan stimulasi terhadap bayi dari aspek motorik, kognitif, bahasa, emosi, kepribadian, moral, spiritual, psikososial. Hasil penelitian menunjukkan peningkatan kemampuan kognitif, psikomotor, dan perkembangan rasa percaya bayi secara bermakna pada keluarga yang mendapat TKT. Peningkatan kemampuan kognitif, psikomotor serta perkembangan rasa percaya bayi lebih tinggi secara bermakna pada keluarga yang mendapat terapi kelompok terapeutik dibandingkan dengan yang tidak mendapat terapi kelompok terapeutik ( $\mathrm{p}$-value $<0,05$ ). Terapi kelompok terapeutik direkomendasikan untuk dilakukan pada tatanan pelayanan kesehatan di masyarakat sebagai bentuk pelayanan kesehatan jiwa bagi keluarga yang mempunyai usia bayi.
\end{abstract}

Kata Kunci: Ability family, stimulation of development, infant development trust, therapeutic group therapy.

\section{Pendahuluan}

Kesehatan jiwa menurut WHO (2001) adalah sebagai suatu kondisi sejahtera dimana individu menyadari kemampuan yang dimilikinya, dapat mengatasi stress dalam kehidupannya, dapat bekerja secara produktif, dan mempunyai kontrkeluargasi dalam kehidupan bermasyarakat. Kesehatan jiwa dikeluargatuhkan oleh semua orang untuk mencapai kehidupan yang harmonis agar tidak mengalami gangguan jiwa. Pelayanan kesehatan jiwa adalah pelayanan yang kontinum yaitu sepanjang rentang sehat sakit, sepanjang hidup yaitu mulai dari pada masa pertumbuhan dan perkembangan anak sejak masih dalam kandungan, masa bayi, masa balita, usia prasekolah, usia sekolah, remaja, dewasa muda, dewasa tengah dan dewasa akhir (CMHN, 2005).

Masa bayi merupakan periode vital karena kondisi fisik dan psikologis bayi merupakan pondasi yang kokoh bagi perkembangan dan pertumbuhan selanjutnya. Pada masa ini terjadi pertumbuhan dan perkembangan motorik, kognitif dan sosial yang cepat. Bulan pertama kehidupan yang kritis meskipun bagian dari masa bayi, sering dibedakan karena adanya penyesuaian fisik yang besar ke keadaan ekstrauterus dan penyesuaian psikologis orang tua. (Wong, 2004)

Menurut Erikson perkembangan masa bayi ini merupakan tahap awal mengembangkan rasa percaya terhadap orang tua. Anak yang memiliki rasa percaya dalam dirinya cenderung untuk memiliki rasa aman dan percaya diri untuk mengeksplorasi lingkungan yang baru. Sebaliknya anak yang tidak memiliki rasa percaya cenderung tidak memiliki harapan harapan positif, sehingga terjadi penyimpangan berupa rasa tidak percaya dan setelah dewasa maka menjadi orang yang mudah curiga dan tidak mampu menjalin hubungan baru dengan orang lain.

Soetjiningsih (1998) menyatakan bahwa kasih sayang dari orang tua akan menciptakan ikatan yang erat (bonding) dan kepercayaan dasar (basic trust). Ikatan batin yang erat, mesra dan selaras yang diciptakan lebih awal dan lebih permanen sangat penting, karena turut menentukan perilaku anak di kemudian hari, menstimulasi perkembangan otak anak, merangsang perhatian anak 
terhadap dunia luar, menciptakan kelekatan (attachment) antara keluarga dan anak, serta meningkatkan rasa kepercayaan diri anak.

Menurut Santrock (2007) rasa percaya dan rasa tidak percaya bukan hanya muncul dan sesudah itu selesai selama tahun tahun pertama anak saja, melainkan akan

muncul kembali pada tahap tahap perkembangan berikutnya. Faktor yang mempengaruhi rasa percaya bayi menurut Soetjiningsih (1998) adalah faktor genetik dan faktor lingkungan. Faktor lingkungan meliputi lingkungan prenatal yaitu lingkungan pada waktu masih didalam kandungan dan lingkungan post natal yaitu lingkungan setelah lahir. Yang termasuk post natal adalah lingkungan biologis, faktor fisik, faktor psikososial, faktor keluarga. Faktor psikososial yaitu stimulasi, stimulasi adalah kegiatan merangsang kebutuhan dasar anak tumbuh dan berkembang secara optimal. Setiap anak perlu mendapat stimulasi rutin dan terus menerus pada setiap kesempatan.

Kemampuan dasar anak yang dirangsang dengan stimulasi terarah adalah kemampuan gerak kasar, kemampuan gerak halus, kemampuan bicara dan bahasa serta kemampuan sosialisasi dan kemandirian. Melakukan stimulasi yang memadai artinya merangsang otak anak sehingga perkembangan kemampuan gerak, bicara dan bahasa, emosi, kepribadian, spiritual, sosialisasi dan kepercayaan pada anak berlangsung secara optimal sesuai dengan umur anak. Dengan stimulasi yang terarah dan teratur tumbuh kembang anak akan lebih cepat dan motivasi belajar akan timbul jika diberikan lingkungan yang kondusif, ganjaran atau hukuman yang wajar, kelompok sebaya, cinta dan kasih sayang serta kualitas interaksi anak-orang tua. (Soetjiningsih, 1998).

Kegiatan stimulasi, deteksi dan intervensi rasa percaya penyimpangan tumbuh kembang yang menyeluruh dan terkoordinasi diselenggarakan dalam bentuk kemitraan antara keluarga (orang tua, pengasuh anak, dan anggota keluarga lainnya), masyarakat (kader, tokoh masyarakat, organisasi profesi, lembaga swadaya masyarakat, dan sebagainya) dengan tenaga professional (kesehatan, pendidikan dan sosial), akan meningkatkan kualitas tumbuh kembang anak usia dini dan kesiapan memasuki jenjang pendidikan formal (Depkes, 2006). Maka sebagai orang tua hendaknya mampu memberikan stimulasi terhadap anak sesuai dengan tugas perkembangannya di lingkungan keluarganya Upaya untuk meningkatkan kemampuan keluarga terhadap kebutuhan kesehatan perkembangan anggota keluarga dengan pendidikan kesehatan, Menurut penelitian yang dilakukan Nasution (2005, dalam Trihadi, 2009) bahwa ada hubungan antara pendidikan kesehatan keluarga dengan pengetahuan keluarga tentang kesehatan. Keluarga mempunyai peranan yang penting dalam memenuhi kebutuhan perkembangan usia bayi diantaranya dengan memahami perkembangan yang normal dan perilaku yang menyimpang, memahami cara menstimulasi rasa percaya bayi. Disamping pendidikan kesehatan, upaya peningkatan kemampuan kesehatan keluarga dapat dilakukan dengan terapi keluarga dalam bentuk psikoedukasi keluarga. Menurut Stuart dan Laraia (2005) bahwa gangguan jiwa dapat disebabkan oleh karena terganggu atau tidak terpenuhinya kebutuhan tahap tumbuh kembang pada masa bayi. Selain pendidikan kesehatan dan psikoedukasi keluarga upaya yang dilakukan untuk meningkatkan kemampuan keluarga dalam memberikan stimulasi dapat juga dilakukan terapi kelompok terapeutik.

Menurut Townsend (2009) terapi kelompok terapeutik merupakan salah satu jenis dari terapi kelompok yang memberi kesempatan kepada anggotanya untuk saling berbagi pengalaman, saling membantu satu dengan lainnya, untuk menemukan cara menyelesaikan masalah dan mengantisipasi masalah yang akan dihadapi dengan mengajarkan cara yang efektif untuk mengendalikan stres. Menurut Smith (2010) terapi kelompok bertujuan untuk meningkatkan hubungan yang positif antara orang tua dan bayi, menurunkan depresi post natal pada keluarga serta perkembangan bayi menjadi optimal. Terapi kelompok terapeutik membantu anggotanya mencegah masalah kesehatan, mendidik dan mengembangkan potensi anggota kelompok dan meningkatan 
kualitas antar anggota kelompok untuk mengatasi masalah dalam kehidupan (Keliat \& Akemat, 2004).

Terapi kelompok terapeutik bertujuan untuk mengembangkan empati diantara sesama anggota kelompok dimana sesama anggota kelompok saling memberikan penguatan untuk membentuk perilaku yang adaptif. Menurut Trihadi (2009) dengan dilakukan terapi kelompok terapeutik terjadi peningkatan kemampuan kognitif dan psikomotor keluarga dalam memberikan stimulasi perkembangan rasa percaya usia kanak-kanak pada keluarga yang mendapat terapi kelompok terapeutik lebih tinggi secara bermakna dibandingkan dengan kelompok yang tidak mendapat terapi kelompok terapeutik. Terapi kelompok terapeutik berpeluang meningkatkan kemampuan kognitif sebesar 45,5\% dan meningkatkan kemampuan psikomotor sebesar 38,5\% setelah dikontrol oleh faktor lain. Oleh karena itu terapi kelompok terapeutik pada keluarga yang mempunyai anak usia bayi perlu dilakukan untuk membantu keluarga mengatasi permasalahannya yang diselesaikan bersama dalam kelompok dan sharing pengalaman dalam memberikan stimulasi perkembangan bayi.

Tujuan Umum Mengetahui gambaran mengenai pengaruh terapi kelompok terapeutik terhadap kemampuan kognitif dan psikomotor keluarga dalam menstimulasi perkembangan bayi serta perkembangan rasa percaya bayi di Kelurahan Batu Ampar Kramatjati Jakarta Timur Tahun 2010.

\section{Metode Penelitian}

Penelitian ini adalah penelitian quasi experimental dengan metode kuantitatif menggunakan desain "Quasi experimental pre-post test kontrol group" dengan intervensi terapi kelompok terapeutik pada tanggal 4 Juli sampai dengan 6 Agustus 2010. Teknik pengambilan sampel secara Purposive sampling. Penelitian dilakukan untuk menganalisa peningkatan kemampuan keluarga dalam menstimulasi perkembangan bayi serta perkembangan rasa percaya bayi dan membandingkan kelompok yang mendapatkan dan yang tidak mendapatkan terapi kelompok terapeutik. Tiap kelompok berjumlah 40 responden. Analisis statistik yang dipergunakan yaitu univariat dan bivariat dengan analisis dependen dan independent sample t-Test serta Chi-square dengan tampilan dalam bentuk tabel dan distrkeluargasi frekuensi.

\section{Hasil dan Pembahasan}

Penelitian dilakukan di kelurahan Batu Ampar dan kelurahan Balekambang Kramatjati Jakarta Timur terhadap 80 responden yaitu 40 responden yang mendapatkan terapi kelompok terapeutik dan 40 responden yang tidak mendapatkan terapi kelompok terapeutik, hasil analisisnya adalah sebagai berikut:

Hasil analisis karakteristik keluarga menunjukkan total 80 keluarga yang dilakukan dalam penelitian ini rata - rata berusia 28,54 tahun dengan usia termuda 20 tahun dan tertua 40 tahun, pendidikan keluarga paling banyak adalah pendidikan dasar (SD dan SLTP) sebesar 86,25\%, pekerjaan keluarga adalah tidak bekerja sebesar $68,75 \%$, tingkat penghasilan keluarga adalah keluarga dengan penghasilan kurang dari UMR (Rp. 768.500,00) sebesar 93,75\% dan urutan anak menunjukan proporsi terbesar adalah multipara yaitu 72,5\%. Analisis usia bayi rata rata 8 bulan dengan usia termuda 6 bulan dan tertua 12 bulan, usia kehamilan keluarga waktu melahirkan rata rata 37,16 minggu usia termuda 37 minggu usia tertua 41 minggu dan berat badan bayi waktu lahir rata rata 3143,12 gram dengan berat badan terkecil 2500 gram dan tertua 4100gram. Hasil analisis menunjukkan bahwa keluarga yang mendapat terapi kelompok terapeutik rata-rata peningkatan 
kemampuan kognitif keluarga dalam menstimulasi perkembangan bayi sebelum dan sesudah intervensi sebesar 9,325 kali meningkat secara bermakna (p-value <0,05). Rata - rata peningkatan kemampuan psikomotor keluarga dalam menstimulasi perkembangan bayi sebelum dan sesudah terapi kelompok terapeutik sebesar 20,275 skor meningkat secara bermakna (p-value <0,05). Hasil uji statistik dapat disimpulkan ada peningkatan yang bermakna rata-rata kemampuan kognitif dan psikomotor keluarga dalam menstimulasi perkembangan bayi sebelum dengan sesudah mendapat Terapi Kelompok Terapeutik (p-value $<0,05$ ).

Peningkatan kemampuan keluarga dalam menstimulasi perkembangan bayi pada kelompok yang tidak mendapatkan terapi kelompok terapeutik. Rata-rata peningkatan kemampuan kognitif keluarga dalam menstimulasi perkembangan bayi pada kelompok yang tidak mendapatkan terapi kelompok terapeutik sebesar 0,275 meskipun secara statistik meningkat, akan tetapi jika dilihat nilai p-value >0,05 dapat disimpulkan kemampuan kognitif meningkat secara tidak bermakna. Rata - rata peningkatan psikomotor keluarga dalam menstimulasi perkembangan bayi yang tidak mendapatkan terapi kelompok terapeutik sebesar 5,9 skor meningkat secara bermakna (p-value < 0,05). Hasil uji statistik dapat disimpulkan ada peningkatan yang tidak bermakna rata-rata kemampuan kognitif keluarga dalam menstimulasi perkembangan bayi pada kelompok yang tidak mendapatkan terapi kelompok terapeutik (p-value > 0,05). Dan ada peningkatan yang bermakna rata-rata kemampuan psikomotor keluarga dalam menstimulasi perkembangan bayi pada kelompok yang tidak mendapatkan terapi kelompok terapeutik ( $\mathrm{p}$-value $<0,05$ ). Hasil dapat dilihat pada tabel berikut:

Analisis Kemampuan Keluarga Dalam Menstimulasi Perkembangan Bayi Sebelum Dan Sesudah Intervensi Terapi Kelompok Terapeutik Pada Kelompok Intervensi Dan Kelompok Kontrol Di Kelurahan Batu Ampar Dan Balekambang Kramatjati Jakarta Timur Tahun 2010

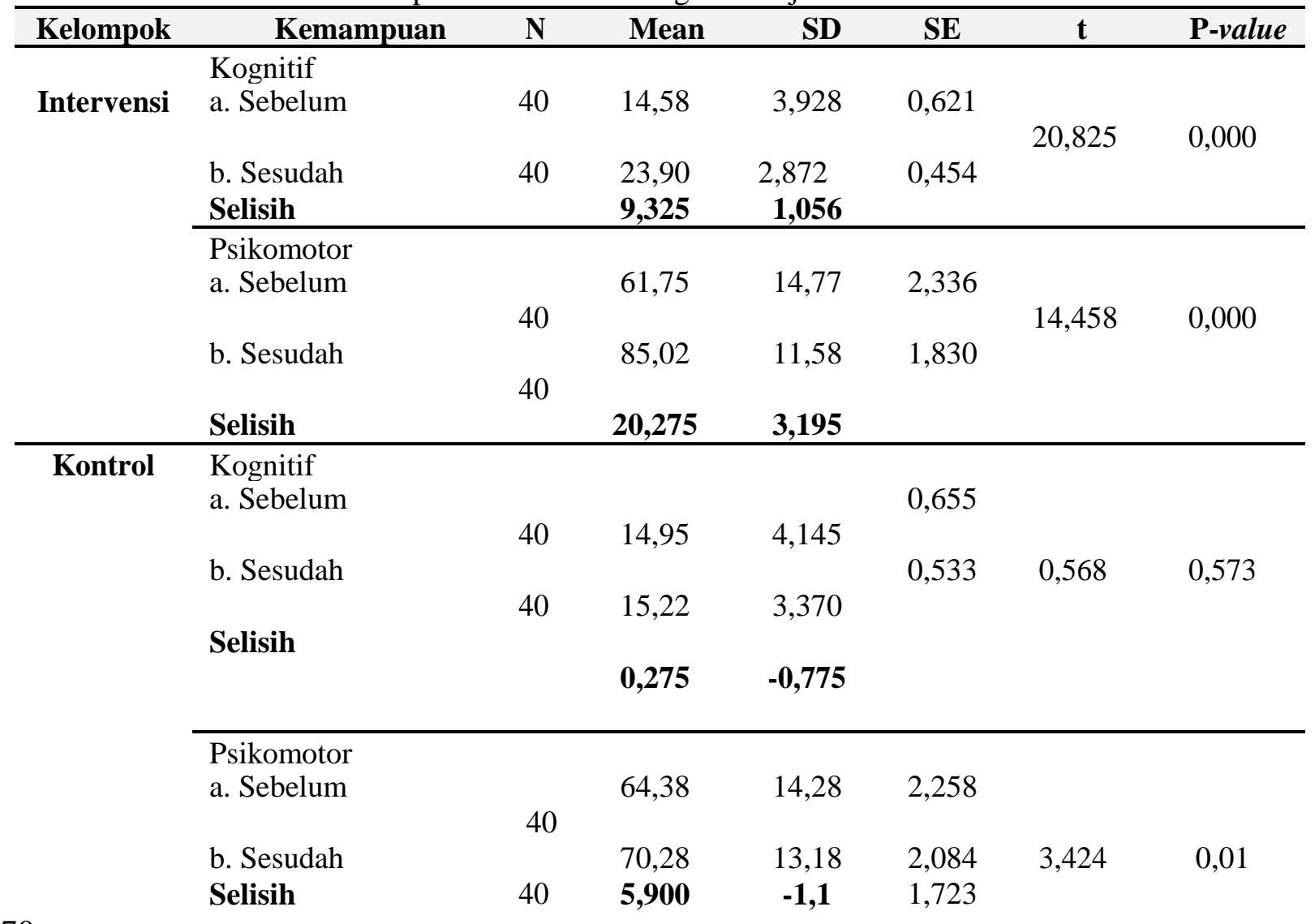


*bermakna pada $\alpha 0,05$

Hasil analisis menunjukkan peningkatan kemampuan kognitif dan psikomotor keluarga dalam menstimulasi perkembangan bayi yang mendapatkan terapi kelompok terapeutik lebih tinggi secara bermakna dibandingkan dengan kelompok yang tidak mendapatkan terapi kelompok terapeutik. Dapat dilihat pada tabel berikut:

Analisis Kemampuan Keluarga Dalam Memberikan Stimulasi Perkembangan Rasa percaya Usia Bayi Sesudah Terapi Kelompok Terapeutik Pada Kelompok Intervensi dan Kelompok Kontrol Di Kelurahan Batu Ampar Dan Balekambang Tahun2010 ( $\mathrm{n}=80)$

\begin{tabular}{cccccccc}
\hline Kemampuan & Kelompok & $\mathbf{N}$ & Mean & SD & SE & T & P value \\
\hline Kognitif & 1.Intervensi & 40 & 23,90 & 2,872 & 0,454 & & \\
& 2. Kontrol & 40 & 15,22 & 3,370 & 0,533 & 12,391 & 0,000 \\
\hline Psikomotor & 1.Intervensi & 40 & 82,02 & 11,575 & 1,830 & & 0,000 \\
& 2. Kontrol & 40 & 70,28 & 13,179 & 2,084 & 4,237 & \\
\hline
\end{tabular}

*bermakna pada $\alpha 0,05$

Hasil analisis menunjukkan bahwa keluarga yang mendapat terapi kelompok terapeutik rata-rata peningkatan perkembangan rasa percaya bayi sebelum dan setelah terapi kelompok terapeutik sebesar 14,525 kali meningkat secara bermakna (p-value < 0,05). Hasil uji statistik dapat disimpulkan ada peningkatan yang bermakna rata-rata perkembangan rasa percaya bayi sebelum dengan sesudah mendapat Terapi Kelompok Terapeutik (p-value < 0,05). Peningkatan perkembangan rasa percaya bayi pada kelompok yang tidak mendapatkan terapi kelompok terapeutik. Rata - rata peningkatan perkembangan rasa percaya bayi pada keluarga yang tidak mendapatkan terapi kelompok terapeutik sebesar 4,5 skor meningkat secara bermakna (p-value < 0,05). Hasil uji statistik dapat disimpulkan ada peningkatan perkembangan rasa percaya bayi pada kelompok yang tidak mendapatkan terapi kelompok terapeutik ( $\mathrm{p}$-value < 0,05). Hasil dapat dilihat pada berikut:

Tabel Analisis Perkembangan Rasa Percaya Bayi Sebelum Dan Sesudah Intervensi Terapi Kelompok Terapeutik Pada Kelompok Intervensi Dan Kelompok Kontrol Di Kelurahan Batu Ampar Dan Balekambang Kramatjati Jakarta Timur Tahun 2010

\begin{tabular}{|c|c|c|c|c|c|c|c|}
\hline Kelompok & Kemampuan & $\mathbf{N}$ & Mean & SD & SE & $\mathbf{t}$ & P-value \\
\hline \multirow[t]{2}{*}{ Intervensi } & $\begin{array}{l}\text { Perkembangan } \\
\text { a. Sebelum }\end{array}$ & 40 & 39,35 & 9,222 & 0,312 & \multirow[b]{2}{*}{12,628} & \multirow[b]{2}{*}{0,000} \\
\hline & $\begin{array}{l}\text { b. Sesudah } \\
\text { Selisih }\end{array}$ & 40 & $\begin{array}{c}53,88 \\
\mathbf{1 4 , 5 2 5}\end{array}$ & $\begin{array}{l}5,779 \\
\mathbf{3 , 4 4 3}\end{array}$ & 0,212 & & \\
\hline \multirow[t]{2}{*}{ Kontrol } & $\begin{array}{l}\text { Perkembangan } \\
\text { a. Sebelum }\end{array}$ & 40 & 40,32 & 7,332 & 1,159 & \multirow{2}{*}{3,988} & \multirow{2}{*}{0,000} \\
\hline & $\begin{array}{l}\text { b. Sesudah } \\
\text { Selisih }\end{array}$ & 40 & $\begin{array}{l}44,82 \\
\mathbf{4 , 5 0 0}\end{array}$ & $\begin{array}{r}3,241 \\
-4,091\end{array}$ & 0,513 & & \\
\hline
\end{tabular}

*bermakna pada $\alpha 0,05$ 
Hasil analisis menunjukkan peningkatan perkembangan rasa percaya yang keluarganya mendapatkan terapi kelompok terapeutik lebih tinggi secara bermakna dibandingkan dengan kelompok yang keluarganya tidak mendapatkan terapi kelompok terapeutik. Dapat dilihat pada tabel berikut:

Tabel Analisis Perkembangan Rasa Percaya Bayi Sesudah Terapi

Kelompok Terapeutik Pada Kelompok Intervensi dan Kelompok

Kontrol Di Kelurahan Batu Ampar Dan Balekambang Tahun2010 (

\begin{tabular}{ccccccc}
\multicolumn{8}{c}{$\mathrm{n=80})$} \\
\hline Kelompok & $\mathbf{N}$ & $\begin{array}{l}\text { Mea } \\
\mathbf{n}\end{array}$ & SD & SE & T & Palue \\
\hline 1.Intervensi & 40 & 53,88 & 5,779 & 0,914 & & \\
2. Kontrol & 40 & 44,82 & 3,241 & 0,513 & 8,639 & 0,000
\end{tabular}

*bermakna pada $\alpha 0,05$

Hasil analisis menunjukan pada kelompok intervensi ada hubungan sedang antara kemampuan kognitif dengan psikomotor keluarga dalam memberikan stimulasi rasa percaya pada bayi $(r=0,353)$ dan berpola positif artinya semakin bertambah kemampuan kognitif keluarga semakin bertambah kemampuan psikomotor keluarga dalam memberikan stimulasi perkembangan bayi, Nilai koefiisien dengan determinasi 0,124 artinya persamaan garis regresi menerangkan 12,4\% kemampuan kognitif keluarga mempengaruhi psikomotor keluarga dalam menstimulasi perkembangan bayi dan sisanya dipengaruhi oleh faktor lain. Dapat dilihat pada tabel berikut:

Tabel Analisis Hubungan Kemampuan Kognitif Keluarga Dengan Kemampuan Psikomotor Keluarga Pada Kelompok Intervensi Di Kelurahan Batu Ampar Tahun 2010

\begin{tabular}{ccccc}
\hline $\mathrm{N}$ & $\mathrm{r}$ & $\mathrm{R}^{2}$ & Persamaan garis & $\mathrm{P}$ value \\
\hline 40 & 0,353 & 0,124 & $\begin{array}{c}\text { Psikomotor }= \\
48,055+1,421^{*} \text { kognitif }\end{array}$ & $0.026^{*}$
\end{tabular}

Hasil analisis menjelaskan pada kelompok intervensi ada hubungan sedang antara kemampuan kognitif dengan perkembangan rasa percaya bayi $(\mathrm{r}=0,378)$ dan berpola positif artinya semakin bertambah kemampuan kognitif keluarga dalam menstimulasi perkembangan bayi semakin bertambah perkembangan rasa percaya bayi, Nilai koefiisien dengan determinasi 0,143 artinya persamaan garis regresi menerangkan 14,3\% kemampuan kognitif keluarga mempengaruhi perkembangan rasa percaya bayi dan sisanya dipengaruhi oleh faktor lain.

Ada hubungan kuat antara kemampuan psikomotor dengan perkembangan rasa percaya bayi $(r=0,574)$ dan berpola positif artinya semakin bertambah kemampuan psikomotor keluarga dalam memberikan stimulasi perkembangan semakin bertambah perkembangan rasa percaya bayi, Nilai koefiisien dengan determinasi 0,329 artinya persamaan garis regresi menerangkan 32,9\% kemampuan psikomotor keluarga mempengaruhi perkembangan rasa percaya bayi dan sisanya dipengaruhi oleh faktor lain. 
Tabel Analisis Hubungan Kemampuan Kognitif dan Psikomotor Keluarga Dengan Perkembangan Rasa Percaya Bayi Pada Kelompok Intervensi Di Kelurahan Batu Ampar Tahun 2010

\begin{tabular}{cccccc}
\hline Variabel & $\mathbf{N}$ & $\mathbf{R}$ & $\mathbf{R}^{2}$ & Persamaan garis & P value \\
\hline Kognitif & 40 & 0,378 & 0,143 & $\begin{array}{c}\text { Perkembangan rasa percaya }=35,705+ \\
0,760^{*} \text { kognitif }\end{array}$ & $0.016^{*}$ \\
\hline Psikomotor & 40 & 0,574 & 0,329 & $\begin{array}{c}\text { Perkembangan rasa percaya }=30,388+ \\
0,286^{*} \text { psikomotor }\end{array}$ & $0.000^{*}$ \\
\hline
\end{tabular}

*bermakna pada $\alpha 0,05$

Hasil penelitian ini sesuai pendapat Trihadi (2009) dengan dilakukan terapi kelompok terapeutik terjadi peningkatan kemampuan kognitif dan psikomotor keluarga dalam memberikan stimulasi perkembangan rasa percaya usia kanak-kanak pada keluarga yang mendapat terapi kelompok terapeutik lebih tinggi secara bermakna dibandingkan dengan kelompok yang tidak mendapat terapi kelompok terapeutik. Menurut Townsend (2005) terapi kelompok terapeutik merupakan salah satu jenis dari terapi kelompok yang memberi kesempatan kepada anggotanya untuk saling berbagi pengalaman, saling membantu satu dengan lainnya, untuk menemukan cara menyelesaikan masalah dan mengantisipasi masalah yang akan dihadapi dengan mengajarkan cara yang efektif untuk mengendalikan stres. Terapi kelompok terapeutik bertujuan untuk mengembangkan empati diantara sesama anggota kelompok dimana sesama anggota kelompok saling memberikan penguatan untuk membentuk perilaku yang adaptif.

Peningkatan kemampuan kognitif terjadi karena pemberian terapi kelompok terapeutik yang merupakan salah satu sumber informasi bagi keluarga untuk meningkatkan kemampuan kognitifnya. Hal ini sesuai dengan Djaali (2008) yang menyatakan kegiatan kognitif meliputi motivasi, konsentrasi, pengolahan dan umpan balik. Dalam kegiatan terapi kelompok terapeutik diperlukan motivasi karena motivasi merupakan faktor internal dari keluarga itu sendiri, sehingga jika ada dorongan maka ia akan mencari tahu, kemudian ia akan memperhatikan dan berkonsentrasi terhadap kegiatan tersebut. Setelah ia mendengarkan maka ia akan membuat penilaian sehingga terjadi umpan balik. Terapi kelompok merupakan suatu proses belajar dan hal ini sesuai dengan Neisser (dalam Notoatmodjo, 2007) yang menyatakan bahwa proses belajar merupakan transformasi dari masukan (input), kemudian masukan tersebut direduksi, diuraikan, disimpan, ditemukan kembali. Belajar juga merupakan suatu teori asosiasi yaitu mengulang ulang didalam mengasosiasikan tanggapan tanggapan, sehingga reproduksi yang satu dapat menyebabkan reproduksi yang lain dalam ingatan kita.

Perilaku adalah setiap tindakan yang dapat diobservasi, direkam dan diukur, suatu pergerakan atau respons (Stuart \& Laraia, 2005). Menurut Skiner (1938 dalam Stuart \& Laraia, 2005) perilaku terjadi jika ada stimulus yang diketahui dan spesifik, bersifat sederhana, sebagai tindakan reflek, atau dipelajari, perilaku dalam suatu kondisi. Respon yang timbul dan berkembang kemudian diikuti oleh stimulus atau perangsang tertentu. Penelitian Rogers (1974 dalam Notoatmodjo, 2007) mengungkapkan bahwa sebelum orang mengadopsi prilaku baru didalam diri orang tersebut terjadi proses berurutan yaitu awareness, interest, evaluation, trial dan adoption.

Peningkatan kemampuan psikomotor ini kemungkinan berkaitan dengan Teori Belajar Sosial Bandura dan Walters (1963, dalam Notoatmodjo, 2007). menekankan pada peran model dalam pembelajaran perilaku, respons sosial dan karakteristik individu didapat dari mengimitasi dan mengkopi perilaku model yang diobservasi individu. Modelling biasanya melibatkan situasi sosial dan hubungan sosial (model dan imitator). Penekanan lain adalah pentingnya penguatan internal. 
Menurut Depkes (2007) stimulasi adalah kegiatan merangsang kemampuan dasar anak agar anak tumbuh dan berkembang. Stimulasi yang dilakukan pada terapi kelompok terapeutik adalah stimulasi motorik, stimulasi kognitif, stimulasi bahasa, stimulasi emosional, stimulasi kepribadian, stimulasi moral, stimulasi spiriual, dan stimulasi psikososial. Menurut Baraja (2007) Dengan memberikan stimulasi maka akan terbentuknya suatu pemahaman, akan menimbulkan rasa penerimaan, dan akan mempengaruhi kepada keterampilan anak. Sehingga stimulasi pada bayi dapat meningkatkan kepercayaan bayi.

Masa bayi menurut Erikson (dalam Potter \& Perry, 2005) merupakan masa trust mistrust yaitu tahap psikososial yang terjadi selama tahun tahun pertama kehidupan. Rasa percaya menuntut perasaan nyaman secara fisik dan sejumlah ketakutan serta khawatiran. Pada saat ini hubungan bayi dengan keluarga sangat penting kalau keluarga memberi makan, membuatnya hangat, memeluk dan mengajak bicara maka bayi tersebut merasa kehadirannya dapat diterima. Sebaiknya kalau keluarga tidak dapat memenuhi kebutuhan bayi maka dalam diri bayi timbul rasa ketidakpercayaan. Hal ini sesuai dengan pendapat Djaali (2008) kalau anak dibimbing dengan baik maka penyesuaian sosial anak akan baik.

Menurut Smith (2010) terapi kelompok bertujuan untuk meningkatkan hubungan yang positif antara orang tua dan bayi, menurunkan depresi post natal pada keluarga serta perkembangan bayi menjadi optimal. Pelaksanaan terapi kelompok terapeutik yang terdiri dari 7 sesi pada sesi 2 sampai sesi 6 beerisi tentang mendiskusikan cara menstimulasi, menjelaskan mengenai tehnik stimulasi perkembangan, mendemonstrasikan cara memberikan stimulasi, keluarga diminta untuk melakukan role play stimulasi perkembangan dan memberikan kesimpulan cara menstimulasi serta menganjurkan keluarga untuk mencoba melatih dirumah. Sehingga dengan adanya terapi kelompok terapeutik akan meningkatkan kemampuan psikomotor keluarga dalam melakukan stimulasi. Stimulasi yang baik dan terarah akan menimbulkan rasa perkembangan rasa percaya karena dengan memberikan stimulasi bayi akan merasa nyaman, meningkatkan kematangan anak sehingga perkembangan rasa percaya anak tinggi.

\section{Simpulan dan Saran}

Karakteristik keluarga yang mempunyai anak usia bayi dengan usia termuda 20 tahun dan tertua 40 tahun dan estimasi interval rata-rata usia keluarga dalam penelitian ini antara 27,39 tahun sampai dengan 29,69 tahun. Sedangkan karakteristik usia bayi termuda 6 bulan dan tertua 12 bulan dengan estimasi rata rata usia bayi dalam penelitian ini antara 7,32 bulan sampai dengan 8,44 bulan. Pengaruh terapi kelompok terapeutik terhadap kemampuan kognitif dan psikomotor keluarga dalam menstimulasi perkembangan bayi serta perkembangan rasa percaya bayi sebelum dan sesudah terapi kelompok terapeutik meningkat secara bermakna. Peningkatan kemampuan kognitif dan psikomotor keluarga dalam menstimulasi perkembangan bayi serta perkembangan rasa percaya bayi yang mendapat terapi kelompok terapeutik lebih tinggi secara bermakna dibandingkan dengan kelompok yang tidak mendapat terapi kelompok terapeutik.

Saran dalam penelitian ini Puskesmas Kramatjati Jakarta Timur hendaknya meningkatkan upaya kesehatan keluarga dan anak dan gizi keluarga dalam kegiatan posyandu pada kelompok sehat yang berbasis komunitas sesuai dengan issue kesehatan jiwa di dunia Puskesmas dan kader memantau kembali untuk pelaksanaan terapi kelompok terapeutik yang sudah berjalan. Konselor hendaknya menjadikan terapi kelompok terapeutik sebagai salah satu kompetensi yang harus dilakukan pada pelayanan kesehatan jiwa di masyarakat (berbasis komunitas). Pengembangan terapi pada kelompok sehat dalam upaya meningkatkan kemampuan keluarga dalam memberikan stimulasi perkembangan sesuai dengan tahapan usia dan menggunakan evidence based dalam mengembangkan teknik pemberian konseling 
kesehatan jiwa pada semua tatanan pelayanan kesehatan dalam penerapan terapi kelompok terapeutik bagi keluarga yang mempunyai anak usia bayi.

\section{Daftar Pustaka}

Ariani (2009). ASI dan tumbuh kembang anak. http://parentingislami.wordpress.com.

Baraja (2008). Psikologi Perkembangan: Tahapan Tahapan Dan Aspek Aspeknya Dari 0 Tahun Sampai Akil Baligh. Jakarta: Studia press.

Cumming; Smith (2010). A decade of parent and infant relationship support group terapy program, http://proquest.umi.com/pqdweb?index $=1 \&$ did $=1944544121 \&$ SrchMode $=1 \&$ sid $=6 \& \mathrm{~F}$ $\mathrm{mt}=6 \& \mathrm{VInst}=\mathrm{PROD} \& \mathrm{VType}=\mathrm{PQD} \& \mathrm{RQT}=309 \& \mathrm{VName}=\mathrm{PQD} \& \mathrm{TS}=1264646724 \& \mathrm{cli}$ entId $=45625$.

CMHN.(2005).modul basic course community mental health nursing. Jakarta :WHO.FIK UI.

Depkes RI. (2006) Stimulasi, deteksi dan intervensi rasa percaya tumbuh kembang anak di tingkat pelayanan kesehatan dasar. Jakarta.

Djaali (2008). Psikologi pendidikan. Jakarta: Bumu Aksara.

Hurlock, E.B (1991)., Developmental Psychology, A Life-Span Approach , McGraw-Hill, Inc.

Ismail (2009). Perkembangan aspek fisik, motorik, kognitif, bahasa, moral, sosial, emosi dan agama dari bayi hingga kanak-kanak http://hbis.wordpress.com

Kania (2007). Stimulasi Rasa percaya Untuk Mengembangkan Kecerdasan dan Kreativitas Anak. http://pustaka.unpad.ac.id/wpcontent/uploads/2010/02/stmiluasi_kecerdasan_dan_kreativitas_anak.pdf

Kartono (2007). Psikologi wanita: mengenal wanita sebagai keluarga dan nenek (jilid 2), Bandung : Mandar Maju.

Keliat \& Akemat (2005). Keperawatan jiwa terapi aktivitas kelompok, Jakarta: EGC.

Noor (2009). Peran perempuan dalam keluarga islam. http://www.google.co.id/url?sa=t\&source=web\&ct=res\&cd=4\&ved=0CA8QFjAD\&url $=$ http $\% 3 \mathrm{~A} \% 2 \mathrm{~F} \% 2$ Fsofia-psy.staff.ugm.ac.id\%2Ffiles $\% 2 \mathrm{~F}$

Potter, P.A. \& Perry,A.G. (2005). Fundamental of nursing : concept, process, and practice, Philadelphia : Mosby Years Book Inc.

Santrock (2007). Child development, Boston: McGraw-Hill

Shives, L.R. (1998). Basic concepts of psychiatric-mental health nursing. (4th ed), Philadelphia: Lippincott.

Stuart,G.W \& Laraia, M.T (2005). Principles and Practice of psychiatric nursing. (7th edition). St Louis: Mosby.

Soetjjiningsih. (1998). Tumbuh Kembang anak. Bali: EGC.

Trihadi (2009). Pengaruh terapi kelompok terapeutik terhadap kemampuan keluarga dalam memberikan stimulasi perkembangan rasa percaya pada usia 1,5-3 tahun di kelurahan bubulak Bogor Timur tahun 2009, FIK-UI: Depok.

Townsend, C.M. (2000). Essentials of Psychiatric Mental Health Nursing. Philadelphia: F.A. Davis Company.

Wong DL. (2004) Nursing Care of infant and children. Texas: Mosby. 
